February 2007

\title{
Enhancing and sustaining teacher professionalism in Pakistan
}

Meher Rizvi

Aga Khan University, Institute for Educational Development, Karachi

Bob Elliott

QUT, Australia

Follow this and additional works at: http://ecommons.aku.edu/pakistan_ied_pdck

\section{Recommended Citation}

Rizvi, M., \& Elliott, B. (2007). Enhancing and sustaining teacher professionalism in Pakistan. Teachers and Teaching: theory and practice, 13(1), 5-19. 
This article was downloaded by: [INASP - Pakistan (PERI)]

On: 11 September 2012, At: 04:00

Publisher: Routledge

Informa Ltd Registered in England and Wales Registered Number: 1072954 Registered

office: Mortimer House, 37-41 Mortimer Street, London W1T 3J H, UK

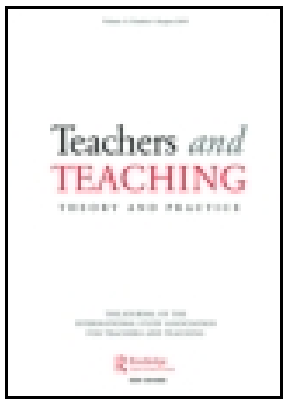

\title{
Teachers and Teaching: Theory and Practice
}

Publication details, including instructions for authors and subscription information:

http:// www. tandfonline.com/ loi/ ctat20

\section{Enhancing and sustaining teacher professionalism in Pakistan}

\author{
Meher Rizvi ${ }^{a} \&$ Bob Elliott ${ }^{b}$ \\ ${ }^{a}$ Aga Khan University, Pakistan \\ ${ }^{\mathrm{b}}$ QUT, Australia
}

Version of record first published: 15 Feb 2007.

To cite this article: Meher Rizvi \& Bob Elliott (2007): Enhancing and sustaining teacher professionalism in Pakistan, Teachers and Teaching: Theory and Practice, 13:1, 5-19

To link to this article: http:// dx. doi.org/ 10.1080/ 13540600601106021

Full terms and conditions of use: http://www.tandfonline.com/page/terms-andconditions

This article may be used for research, teaching, and private study purposes. Any substantial or systematic reproduction, redistribution, reselling, loan, sub-licensing, systematic supply, or distribution in any form to anyone is expressly forbidden.

The publisher does not give any warranty express or implied or make any representation that the contents will be complete or accurate or up to date. The accuracy of any instructions, formulae, and drug doses should be independently verified with primary sources. The publisher shall not be liable for any loss, actions, claims, proceedings, demand, or costs or damages whatsoever or howsoever caused arising directly or indirectly in connection with or arising out of the use of this material. 


\title{
Enhancing and sustaining teacher professionalism in Pakistan
}

\author{
Meher Rizvi ${ }^{\mathrm{a} *}$ and Bob Elliott ${ }^{\mathrm{b}}$ \\ ${ }^{\mathrm{a}}$ Aga Khan University, Pakistan; ${ }^{\mathrm{b}}$ QUT, Australia
}

\begin{abstract}
This paper presents a conceptual framework for fostering teacher professionalism in Government primary schools in Karachi, Pakistan. The framework identifies various stages for enhancing and sustaining teacher professionalism. These stages have been derived from in-depth multiple case studies of four Government primary schools in Karachi where reforms have been occurring. In order to enhance and sustain professionalism among the teachers they need to be provided with opportunities to expand their capabilities and, consequently, the reform managers will need to encourage them through various stages of development. Amongst the various stages are those of involvement, initiation and engagement and developing collaborative school cultures. The theory building provided in the paper will be extremely important in the current context of Pakistan where several initiatives are being undertaken to reform and improve the Pakistani Government school system. The sustainability of such reforms requires the building of teachers' professional capacity and enhancing their professionalism.
\end{abstract}

Keywords: Conceptual framework; Professional development; School reforms; Teacher professionalism

\section{Introduction}

In the past decade in Pakistan a number of education reform agendas have been planned and implemented. The research reported in this paper indicates that most teachers are willing to give these reforms a try if they are likely to lead to improved teaching and learning and, in doing so, enhance their professionalism (Rizvi, 2003). After a consideration of the context of the Government primary schools in Pakistan and document analysis of reform initiatives in Karachi, teacher professionalism was conceptualized in terms of four dimensions. These are teacher efficacy, teacher practice, teacher collaboration and teacher leadership (for a cogent rationale and detailed

\footnotetext{
*Corresponding author. Institute for Educational Development, The Aga Khan University, 1-5/
} B-VII, F.B. Area, Karimabad, Karachi, 75950, Pakistan. Email: meher.rizvi@aku.edu 
description of the four dimensions of teacher professionalism, see R;izvi \& Elliott, 2005). These dimensions of professionalism define teachers as:

Professionals who are committed and efficacious, possess specialized knowledge and expertise, collaborate with colleagues and use professional discretion, and have the potential to develop an active and reflective teaching profession. (Rizvi, 2003)

However, whether the teachers' intrinsic drive will continue to give them strength to face the challenges they will encounter and continue to learn on their own, perhaps in the absence of opportunities and support, is a highly problematic issue. Failing to find the level of satisfaction in the classroom and in the school, even the most dedicated teachers may begin to question their roles as professionals.

In the first part of the paper we discuss the problems associated with the quality of schooling in Pakistan and explore the root causes of those problems. This sets the scene for the second part of the paper where the research methodology and research process are discussed. In the subsequent section of the paper, the detailed process leading to the development of an elaborated framework of enhancing and sustaining teacher professionalism is presented. A detailed explanation of this process is important in order to highlight how various stages of developing teacher professionalism have emerged from the in-depth analysis of the case studies. The elaborated framework is also strengthened by reference to literature. In the concluding section we argue the significance of the framework in the current context of school reforms in Pakistan.

\section{The Government education system and the quality of school education in Pakistan}

Even though Pakistan's education system has expanded substantially since independence in 1947, debate continues about the quality of education particularly in Government schools (Retallick \& Farah, 2005). Of the 20 million children in the age group 5 to 9 years old, approximately 12 million enroll in schools but $50 \%$ drop out before completing primary education (Ministry of Education, 1998).

Schooling is provided in Pakistan by a range of different systems of varying quality and these include:

- A Government system of primary and secondary schools

- A private school system (community, non-profit and for-profit schools)

- A religious school (madrassah) system.

In the private school sector, principals, teachers, students, and community take their schools rather seriously. Madrassahs follow a curriculum heavily dominated by religious subjects (SPDC, 2003). However, the Government has started redesigning madrassahs' curriculum to also include secular subjects.

The major problems with the quality of education in Pakistan are to be found in the Government school system (ICG, 2004) that caters for four out of five children who attend school. A significant cause of the crises in quality of education is the extent of poverty in Pakistan. Pakistan ranks 68 out of 174 countries in the Human 
Poverty Index (SPDC, 2000). Pakistan's expenditure on education of $1.8 \%$ of GDP (SPDC, 2003) seems to indicate that education is not accorded the protection enjoyed by other social institutions (Hoodbhoy, 1998). Other factors contributing to the ineffectiveness of the Government education system in Pakistan are political and bureaucratic interference, lack of accountability and sound management practices, and lack of high quality teacher and staff training (Bergman \& Mohammad, 1998).

In Pakistan, teacher salaries are generally low, the physical plant is usually poor with deplorable classrooms, and there is a lack of career opportunities for advancement in the profession. Teaching in primary schools is generally characterized as rote learning and memorization of the facts to be regurgitated on internal school exams.

Nearly all the policies seeking to address these conditions have emphasized the importance of quality education in primary schools and have reiterated the improvement in teaching standards as one way of improving quality. Yet, the improvement in terms of teacher training has been minimal. Primary school teachers have not been recognized as professionals who can play an enormously important role in transforming life within the schools. Teachers have almost no involvement in policy planning and this seems to signify the teachers' role as an implementer of plans to achieve objectives rather than as capable and active professionals.

The Pakistan Government has recently embarked on a very ambitious Education Sector Reform (ESR) Programme, which contains a number of measures for overhauling and modernizing the Government education system (Ministry of Education, 2001). Teacher professional development, which is a major focus of systemic reform initiatives in many countries (Fullan, 1997, 2000; Hargreaves, 1997; Hopkins, 1998; Day, 1999; Garet et al., 2001), must also be given due importance in Pakistan if Government schools are to improve.

\section{Research methodology}

A multiple case study design (Merriam, 1998; Yin, 2003) was employed to explore the ways in which the selected Government primary schools in Karachi were being reformed in order to enhance and sustain professionalism among the teachers. The case study approach was particularly suited to this research because the phenomenon (enhancing and sustaining teacher professionalism) was very much embedded in the context (Government primary schools in Karachi). By concentrating on a single phenomenon in four case study sites, we were able to reveal the interaction of significant factors characteristic of the phenomenon and construct an elaborated framework of enhancing and sustaining teacher professionalism in the schools. In attending to specific and holistic issues, multiple cases were able to generate both unique and universal understandings (Simons, 1996).

\section{Case sites}

Four Government primary schools were selected for investigation using purposive sampling technique. These schools were selected because they were regarded as a good 
representation of the phenomenon under study and matched the criterion of successfully implementing the reform agendas. These schools were to work as 'light-house schools' for other schools. The four case study schools were unique in their context, yet they operated within the same bureaucratic organization of the Government education department and they shared many common features in terms of their overall operation. Pseudonyms have been used to represent the four schools in order to maintain their anonymity.

The Alif Government Girls' Primary School (GGPS) was selected as representative of schools in which Teachers' Resource Centre (TRC) (1999) implemented their Primary Education Programme (PEP), which had a whole school development focus. TRC is a non-profit, non-Government organization working to improve the quality of children's learning through teacher education and development programs. The Bay GGPS was chosen from among the many schools which were reconstructed into school development centres for the In-service Teacher Training (INSETT) Programme. The INSETT Programme was one of the main components of the Sindh Primary Education Development Programme (SPEDP) which was a large-scale programme initiated by the Department of Education, Government of Sindh (Bureau of Curriculum and Extension Wing, 1997). The Book Group (1996), which is a private book publishing and curriculum development organization, implemented administrative reforms and major pedagogical innovations such as introducing interesting and relevant curriculum in the Pay GGPS. The Tay Government Girls and Boys School was adopted in 1999 under the Sindh Education Foundation's (SEF) (1998) Adopt a School Programme. SEF is a semi-autonomous organization undertaking educational initiatives in the disadvantaged areas of Sindh.

\section{Research process}

In order to gain in-depth understandings of the phenomenon under study, the principal author spent eight months in the four case sites. She is a Pakistani national resident in Karachi and hence has a better capacity to interpret the nuances of the interviews and the context. At the same time she has traveled outside the country and is thus able to also bring an 'outsider' perspective. In this sense both an insider and outsider perspective have been brought to the research.

Data were collected through interviews and observation. Four teachers, the school principal and the reform manager were interviewed from each case site. Four individual interviews of 30-45 minutes with each teacher and principal and one focus group interview of approximately 60 minutes were conducted in each school. One interview with each of the four reform managers lasted 45-60 minutes. All the interviews were tape recorded with the respondents' permission. The principal author personally conducted and transcribed each interview. Personal transcription of all the interviews enhanced the reliability and the trustworthiness of the interview data. Observations of the school setting and informal conversations with the teachers were documented as field notes.

The analysis involved two stages-within-case and cross-case analysis (Merriam, 1998). The initial stage of analysis coincided with the eight month long data collection 
phase when each of the tape-recorded interviews with the participants was listened to, transcribed and tentative interpretations were drawn. These were member checked with all the participants in the study in order to enhance the validity of the findings. For the second phase of analysis, the concurrent flows of data reduction, data display and verification (Miles \& Huberman, 1994) were carried out using NVivo. Constant comparative analysis was used for unitizing and categorizing data, and latent content analysis was used to discover the underlying meaning of the data (Tashakkori \& Teddlie, 1998). The latent content analysis both with in-case and across-case was important to highlight the emerging themes and issues, and to bring the data together to explore ways in which the Government primary schools could be reformed to further enhance teacher professionalism.

Although this was a multiple case study with within-case and cross-case analysis, it has been decided for reasons of clarity and precision to draw data from one case (Alif) to illustrate the issues and provide evidence for the conclusions.

\section{An informed conceptual framework of enhancing and sustaining teacher professionalism}

Through our analysis of the data, we became increasingly aware that the process of developing teacher professionalism was greatly influenced by the reform managers' attitudes. Those reform managers who were empathic and understanding towards teachers' problems and who involved teachers in the school developmental plans were able to foster a willingness and motivation among teachers to work harder and sustain improvements. On the other hand, those reform managers who saw their role as merely prompting teachers to strictly follow the professional standards, engendered higher stress levels among the teachers. This focused our attention on laying the foundation of teacher professionalism by building relationships and promoting teacher involvement as a first stage of initiating reforms and facilitating teacher development.

We also found that the process of developing teachers' capabilities and providing them with opportunities to engage in interesting tasks had not been quite the same in all the cases. For example, the teachers who were provided with opportunities to learn and develop their capabilities by doing, reading and reflecting about their context in their school were able to construct new knowledge and beliefs about content, pedagogy and learners. This was reflected in the quality of work that they produced in their schools. On the other hand, the teachers whose capacities were developed in workshops away from school found it difficult to implement learning from workshops in their schools. These findings focused our attention on the complexities in the stage of developing teachers' professional capabilities and providing them with opportunities to expand their capabilities.

For those teachers who indicated that they valued the opportunities to work on interesting tasks, many also reported that they required time, resources and administrative systems to help them learn. These teachers appeared to be pointing out an important stage in their professional development. This is a third stage of sustaining teacher professionalism by building support systems, which could sustain the process of 
learning once the specific activities of reform have ceased. The research evidence also highlighted the enormous contribution of the school principals in providing such support and sustaining improvements.

The informed conceptual framework, which identified a three-stage model, can be used to facilitate a more in-depth discussion on ways in which the schools could be reformed to enhance and sustain teacher professionalism.

\section{The stage of laying the foundations of teacher professionalism}

Laying the foundation of teacher professionalism implies a process of developing readiness in the teachers to be engaged in the professional development programmes and the school development activities. The research illustrated the variations in ways each reform initiative laid the foundation of developing teacher professionalism. The TRC used their friendly attitude to lay the Alif school development foundations and a teacher recalled how this attitude worked as a catalyst in developing the staff capacity and hence their professionalism:

Sometimes, when the children keep on asking us the same thing again and again, we become irritated. However, TRC never became irritated. They kept on explaining the same thing again and again, till it was clear to us. It is because of their good attitude that we have developed so much confidence.

TRC also involved teachers in the initial planning and in the subsequent planning of the school development plans through the school development review meetings and listened to their concerns. As the two teachers from the Alif School pointed out:

I was included in the initial planning. We prepared the action plan. Time limits were set.

Then that school development plan was brought to the school.

They asked us what we wanted to learn and the areas in which we needed the training.

Based on our suggestions they planned for the learning sessions for us.

Studies suggest that teacher involvement in professional development increases motivation and commitment to learn and therefore is an essential component of effective professional development (Ashdown, 2002; Guskey, 2002). Day (2000) argues that those who are initiating change can benefit greatly by listening to those (teachers) who are implementing change and demonstrating that extra time, energy and support are needed.

In cases such as the Pay and the Tay Schools, reform managers laid the foundations of teacher professionalism by modifying the school structures and by standardizing practices in the school. This strategy streamlined teachers' routine tasks. However, some teachers became stressed when their work was checked and they were held accountable for their work. Other studies have reported on tensions between individual teachers' perceived needs for self-improvement and system demands of teachers for changes in curriculum and teaching approaches (Bell, 1991; Ashdown, 2002). The authors categorize such tensions in their research as dissonance, a lack of congruence, resistance or discontinuities. 
When foundations are laid to achieve school improvement and teacher development objectives in schools such as the Karachi's Government primary schools, which have centralized management and which comprise teachers whose socio-economic and professional status is generally low (Hoodbhoy, 1998), some important matters need to be considered.

First, because there will always be some teacher resistance, it is important to listen to the teachers. Fullan (1999) stresses that having empathy for those who are different from ourselves is difficult but essential. Secondly, teachers are already working under a top-down system and they do not want a second party coming and telling them what to do. They are probably looking for horizontal rather than vertical communication.

The stage involving the process of developing teachers' professional capabilities and providing them with opportunities to exploit their capabilities

The very nature of the reforms and the reform managers' views about the processes by which teachers could develop their professionalism influenced the different ways in which the reform initiatives sought to develop teachers' capabilities and provide them with opportunities to expand these capabilities. This leads to the question of how teachers' capabilities can best be developed. This question is closely tied to the questions of where teacher learning is placed, what teachers need to know in order to develop their capabilities and what opportunities teachers require to expand their capabilities.

\section{Where teacher learning is placed}

Teachers need to relearn and reconstruct their professional knowledge with the help of professional development programmes in order to further enhance their professionalism. Alif School presents a good example of what McLaughlin (1997) describes as learning by doing, reading and reflecting, collaborating with other teachers, looking closely at students and their work, and sharing what they see. In the words of two teachers:

At the end of the week, we also write down our own evaluation. We write down whether our lesson was effective or not. If the children did not take interest in the lesson, we try to find out the cause of that.

We help each other. We discuss different things. By working together, there has been a tremendous increase in our knowledge.

The way in which they designed workshops with intervals between key activities appears to suggest that the TRC recognized the importance of helping teachers learn by providing them with an opportunity to embed their learning in everyday activities (Lieberman \& Miller, 1991).

The INSET training assumed that the teachers could simply transfer knowledge from teacher training sessions to their 'real' classrooms (McLaughlin, 1997). However, the respondents in the case sites reported that when the teachers who had 
received this training went back to their respective schools, they practiced the new skills for some time but then they reverted to their old practices.

This evidence suggests that placing teacher learning activities both in the professional development courses and in everyday school activities is directly related to developing teacher capabilities, and hence their professionalism.

The literature from many western countries also supports this position. According to Mclaughlin and Oberman (1996), rebuilding professionalism requires professional development opportunities that extend beyond mere support for teachers' acquisition of new skills or knowledge to incorporate occasions for teachers to critically reflect on their practice and fashion new knowledge and beliefs about content, pedagogy and learners. Day (1999) argues that some of the most effective forms of professional development and learning appear to be ones that are embedded in the job and ingrained in the culture of teaching. Retallick (1999) also advocates workplace learning as vital for not only teachers' success in the classroom but also for their overall professional development.

\section{What the teachers need to know in order to enhance their professionalism}

The research findings illustrate that the teachers felt more capable about performing different tasks when they had relevant professional knowledge about performing those tasks. As this teacher from the Alif School pointed out: 'When I have the lessons planned and I have prepared myself mentally and also with the different resources, then I'm not scared or worried about anything'.

In the case of the Alif, the Bay and the Pay Schools, it was when the reform managers developed teachers' professional knowledge about the subject matter, pedagogy and learners that the teachers were able to achieve good results with their students. This example from Alif School illustrates how the reform agency developed teachers' capabilities.

TRC taught us the ways of conducting a meeting, the ways of planning a lesson together, the ways of doing yearly planning together, the ways of involving children in classroom routines and developing friendly relationships with them.

When the new teacher practices improved teachers' effectiveness and relationships with the students, they came to believe that they were capable of achieving good results. In the Tay School where the teachers were not given any training to renew and enhance their professional capabilities, no change in teacher classroom practice was reported.

\section{What opportunities help teachers make the most of their capabilities}

The phrase 'providing teachers with the opportunities' needs to be elaborated. Specifically, it refers to those opportunities that enable teachers to develop the skills they need.

The research findings have indicated that opportunities that are likely to develop teacher professionalism are those that firstly help teachers learn about different 
strategies but then create situations where they can actually implement them in their schools. This is what happened at the Alif School where, according to the teachers, they were provided with opportunities to bring their learning from the workshop and apply it in the classroom to observe the effectiveness of the new teaching skills and knowledge with the children.

Now children work in groups so that they can work by helping each other. We let children dramatize a play or a poem in the class. I think this is a better method.

Now when I teach, I teach with the help of the things in the classroom and in the environment. For example, how many fans are there in the class?

According to King and Newmann (2000) teacher learning is most likely to occur when the teachers have the opportunities to study, to experiment with, and to receive helpful feedback on specific innovations.

The teachers have suggested that they wished to be provided with opportunities to enhance their professional capabilities.

The education department should prepare learning programmes for the teachers so that their interest is maintained and we get opportunities to meet with the other people and learn from them.

These suggestions have implications for the education department to arrange such learning seminars and learning programmes where teachers get opportunities to collaborate and learn from one another.

\section{The stage involving the process of sustaining teacher professionalism}

The research illustrated that there are differences in the way each reform initiative attempted to redesign school structures to support and sustain teacher professionalism. Thus the 'provision of opportunities' needs to include the provision of support structures for teachers. In examining which types of support structures best sustain teacher professionalism, various issues need to be considered.

The Alif School story demonstrated that while the teachers faced the challenges of experiencing success with the new child-centered approaches and experimenting with the newly gained knowledge and learning, TRC provided them with the professional support and guidance in the form of regular follow-up work and feedback, administrative collective work, and group discussions. As this teacher reported:

TRC used to sit at the back of my class, taking notes. After the class, they sat with me and advised me to work upon my errors. They checked my lesson diary and pointed out what more I should be adding in my lesson. They also told me what they had observed missing in my class. They would check my way of speaking, my voice tone. They checked everything in my class.

The Alif School principal continued to provide the teachers with professional support. She took some management steps such as preserving teachers' work, letting teachers use each others' resources, and introducing extra-curricular activities in the school to provide teachers with the necessary support. In the words of one teacher: 
'Our principal observes our work, guides us if we have difficulty and evaluates our performance to find out whether the work is being done or not'.

The professional support started by the TRC team and continued by the school principal was extremely important for sustaining teacher professionalism in the Alif School. Teachers demonstrated commitment and willingness to sustain improvements in their school.

We keep generating new ideas. Now we know that we can teach using different methods. Sometimes, children bring ideas and ask us to teach in that way. The activities make the children very happy. So, we do not want to ever stop working in this way. If required, we will also help other teachers work in the same manner.

The teachers also recognized the need for emotional support as an important ingredient for sustaining improved practices in the schools. The Alif School teachers, whose progress was noted and appreciated by the TRC, realized how important emotional support was in developing teachers' confidence and teacher practice.

If you can find somebody who can appreciate what you are doing, then in your heart you become certain that you can produce good work. We then get a 'We can do' feeling. TRC did this a lot with us.

In fact, it was the emotional support combined with professional guidance that enabled TRC to develop a group of teachers in the Alif School who were confident, shared a common vision and a deep sense of commitment to sustain improvements in their school. Teachers reflect this commitment in these words:

We have built a good reputation for our school. Our school is praised everywhere. We must look forward and progress. If somebody's paying us so much attention, then we must also do something good.

In addition to the professional and emotional support, the teachers in the case study schools also required administrative and structural support from their education department to put their beliefs and capabilities into practice and sustain their professionalism. As this teacher from the Alif School pointed out:

A teacher finds it very difficult to prepare teaching aids because she has no free period. The teacher takes this heap of material home to prepare teaching resources. The teachers should be given a free period for lesson planning and for making teaching aids.

The teachers in the case sites wanted to organize their classes on modern concepts of groups and adorn them with children's work, but when they had to reset their classes every afternoon for the afternoon shift, it was not surprising to observe that they reverted to a traditional classroom pattern. In the Alif School, teachers would like to meet on a regular basis for discussions if a separate block of time could be set aside for it.

Based on these findings an argument can be made that in order to sustain their professionalism teachers need a 'hybrid' support structure, which has elements of professional guidance (follow-up of the training sessions, feedback to teachers about their work, group discussions, collective administrative work, cooperative work techniques, teachers learning from one another in a planned manner), an emotional touch 
(encouraging teachers for trying, listening to teachers, respecting teachers' points of view, praising teachers' efforts, promoting teachers' work), proper structures and school administration (provision of teaching resources, availability of teaching staff, regular school supervision, time for teacher learning, safe and clean working conditions) and an inspiring leader as the head of the school.

\section{Synthesis}

The research findings from the four cases can be brought together to formulate a comprehensive and an informed framework of enhancing and sustaining teacher professionalism. This framework is represented diagrammatically in Figure 1.

The informed framework (Figure 1) is rich and complex. This complexity and richness is grounded in the findings of the research and reveals the complexity of developing teachers' professionalism. The boxes in Figure 1 are numbered to facilitate the discussion of the theory building process presented diagrammatically.

The success of school reforms (Box 1) depends on enhancing and sustaining teacher professionalism (Box 10). Box 2 in the figure illustrates that even before the process of developing teacher professionalism begins, it is important to lay the foundations of the reforms by involving teachers and building positive relationships with them. The strength of the relationships between the school reform and teacher professionalism depends on how, and to what extent, teachers' capabilities are developed (Box 4) and what types of opportunities (Box 5) they are provided with to expand their capabilities. Teachers require professional development programmes (Box 3), which enhance their professional knowledge and skills and which do not end at the training centers. For professional development to continue at the school level, it is important that the teachers are provided with opportunities to embed their learning from the training sessions into the school activities (Box 6). This research has demonstrated that it is when the teachers achieve success in embedding learning at the school level that their professional practice improves and they begin to believe that they are capable of achieving different tasks.

The arrows joining Boxes 5 and 6 to Box 7 illustrate that in order to help teachers achieve success in enhancing and sustaining their professionalism, opportunities need to be extended to include structures that provide the teachers with the professional support to further enhance their professional practice; emotional support to help them believe that they are capable of achieving; structural and administrative support to work collaboratively with other teachers and undertake leadership roles (Box 7). Once back in schools, the school principal takes the central position, as Box 8 illustrates. The extent to which teachers are able to benefit from the opportunities presented to them and further enhance their capabilities (Box 9) will depend on the school principal's training and commitment.

In the terms of this framework, teacher professionalism is enhanced and sustained when the teachers are provided with the professional knowledge and skills to improve their capabilities in performing both class- and school-related tasks, and opportunities to translate these professional knowledge and skills into classroom and 


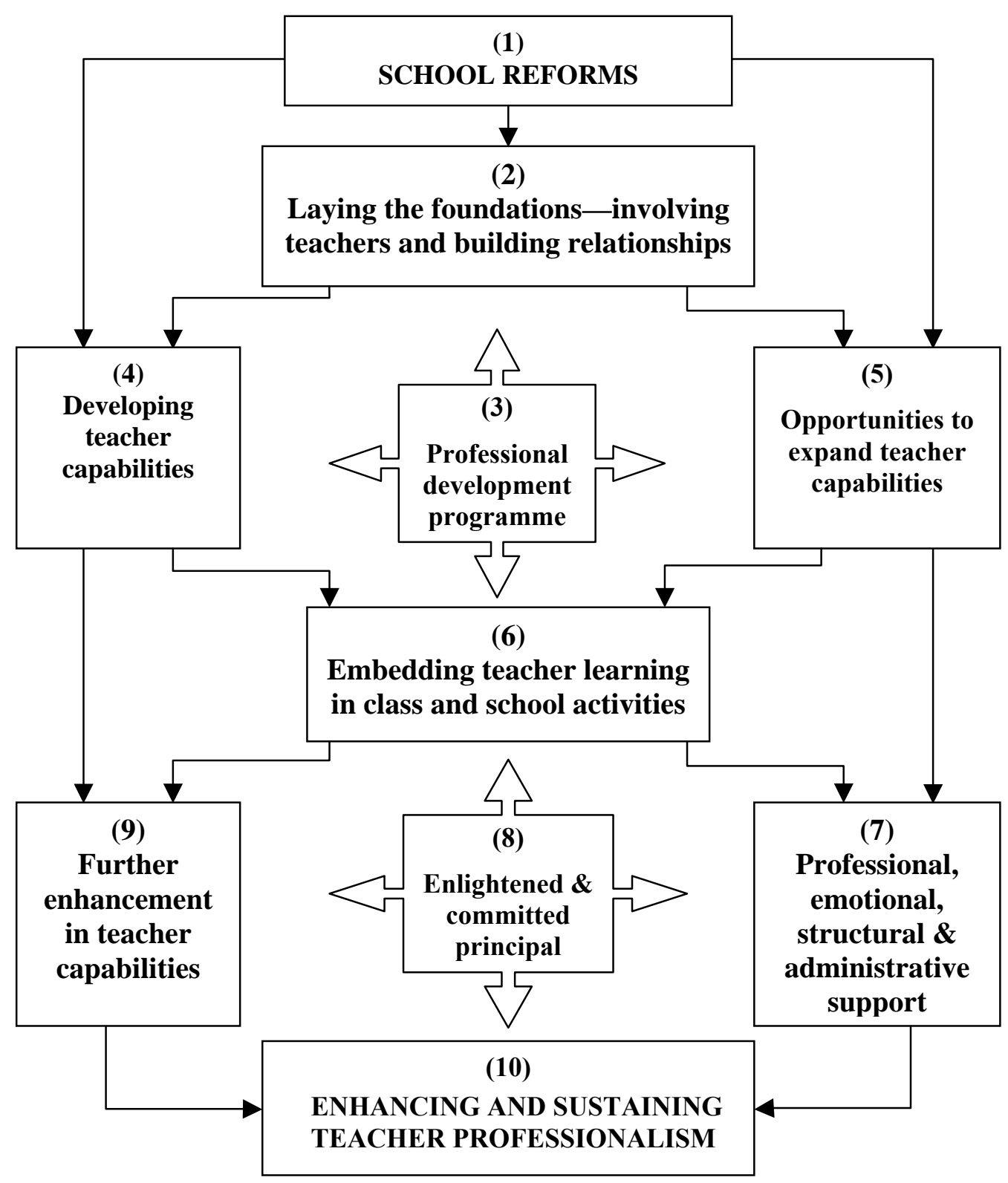

Figure 1. Informed framework of enhancing and sustaining teacher professionalism

school activities to make the most of their capabilities. The strength of these relationships between school reforms and teacher professionalism depends on how successful the reform managers have been in enhancing and sustaining teacher professionalism.

On the basis of this theorizing it can be assumed that the success of school reforms depends on enhancing and sustaining teacher professionalism and that depends on 
the dynamism with which the reform managers successfully take the teachers through the various stages of teacher development. This research proposes three such stages:

- A stage of building relationships with the teachers and involving them in developmental processes.

- A stage of initiating professional development programmes that develop teachers' capabilities and provide them with opportunities to embed their learning in school activities and expand their capabilities.

- A stage of developing schools into collaborative cultures with the help of an enlightened principal and hybrid support structures for sustaining teacher professionalism.

\section{Conclusion}

Under the Education Sector Reform Programme, the present Government of Pakistan has begun upgrading existing primary schools to elementary facilities, initiating a non-formal primary education programme for the 5- to 9-year-old age group in disadvantaged areas and initiating early childhood education in Government schools (Ministry of Education, 2001). Professional Development of the administrators and educators to further enhance their professional capabilities has been recognized as a crucial factor for the successful implementation of developmental plans, particularly at the Government school level. This research takes the first steps in laying a conceptual framework for the processes that stimulate and support teacher professional development with a view to enhance and sustain teacher professionalism in Government primary schools in Pakistan.

The framework arising from the research stresses that teacher preparation and development is important, but it is also important to realize that even if the best and the brightest teachers are not provided with a work environment where they can be successful, their preparation and development will be of little value either to them or their school. Hence, the enhancement of teacher professionalism that can transform life within schools depends on the dynamism with which the reform mangers can move teachers through appropriate stages of development.

The theory building provided in this paper offers a more informed perspective about school reform and teacher professionalism as a result of blending grounded research with specific relevant literature. Based on this theorizing, such schools can be reformed and restructured to further enhance and sustain teacher professionalism for long-term school development. It is important to remember that it is just that - a theory and not a foolproof recipe. Enactment requires professional judgement. It will be the blend of different elements in the schools, the particular school context and political will that will decide how professionalism can best be fostered in specific Government primary schools in Karachi. However, this theorizing has emerged as a result of research, which is rich in contextual information, and linked to broader Western related research and literature. Therefore, it has important 
implications for policy makers to regard teachers as change agents capable of generating knowledge and of making change happen, rather than as passive recipients and users of knowledge.

\section{Notes on contributors}

Meher Rizvi is Assistant Professor of Education in the Institute of Education at the Aga Khan University, Karachi, Pakistan. She has extensive teaching experience in a range of educational contexts, including primary schools, secondary schools, teacher education colleges, and national and international universities. Her primary research interests include teacher professionalism and professional development, educational change and school improvement, instructional leadership, and primary education reforms and policy implications.

Bob Elliott is an Associate Professor and Director of International Development in the Faculty of Education at Queensland University of Technology, Australia. He has extensive experience in the area of teacher development in the South East Asia region, having worked on consultancy projects in many countries. His research interests are in teacher development and curriculum leadership.

\section{Notes}

1. Sindh is one of the four provinces of Pakistan. Karachi, which is the largest city of Pakistan, is also situated in the province Sindh.

\section{References}

Ashdown, J. (2002) Professional development as 'interference'? Insights from the reading recovery in-service course, in: C. Sugrueo \& C. Day (Eds) Developing teachers and teaching practice (London, RoutledgeFalmer), 116-129.

Bell, L. (1991) Approaches to the professional development of teachers, in: L. Bell \& C. Day (Eds) Managing the professional development of teachers (Milton Keynes, Open University Press).

Bergman, J. \& Mohammad, N. (1998) Primary and secondary education structural issues, in: P. Hoodbhoy (Ed.) Education and the state: fifty years of Pakistan (Karachi, Oxford University Press), 23-42.

Bureau of Curriculum and Extension Wing (1997) SPEDP-II: school development component (Jamshoro, Bureau of Curriculum and Extension Wing).

Day, C. (1999) Developing teachers: the challenges of lifelong learning (London, Falmer).

Day, C. (2000) Stories of change and professional development: the costs of commitment, in: A. Fernandez, C. Day, T. E. Hauge \& J. Moller (Eds) The life and work of teachers (London, Falmer), 109-129.

Fullan, M. (1997) The complexity of school change, in: M. Fullan (Ed.) The challenge of school change (Cheltenham, Hawker Brownlow), 27-45.

Fullan, M. (1999) Change forces: the sequel (London, Falmer).

Fullan, M. (2000) The three stories of education reform, Phi Delta Kappan, 81(8), 581-584.

Garet, M. S., Porter, A. C., Desimone, L., Birman, B. F. \& Yoon, K. S (2001) What makes professional development effective? Results from a national sample of teachers, American Educational Research fournal, 38(4), 915-945. 
Guskey, T. R. (2002) Professional development and teacher change, Teachers and Teaching: theory and practice, 8(3/4), 381-391.

Hargreaves, A. (1997) The four ages of professionalism and professional learning, UNICORN, 23(2), 86-108.

Hoodbhoy, P. (Ed.) (1998) Education and the state: fifty years of Pakistan (Karachi, Oxford University Press).

Hopkins, D. (1998) Tensions and prospects for school improvement, in: A. Hargreaves, A. Lieberman, M. Fullan \& D. Hopkins (Eds) International handbook of educational change (London, Kluwer Academic), 1035-1055.

ICG (2004) Pakistan: reforming the education sector (Islamabad/Brussels, International Crises Group).

King, M. B. \& Newmann, F. M. (2000) Will teacher learning advance school goals? Phi Delta Kappan, 81(8), 576-580.

Lieberman, A. \& Miller, L. (Ed.) (1991) Staff development for education in the '90s: new demands, new realities, new perspectives (2nd edn.) (New York, Teachers College).

McLaughlin, M. W. (1997) Rebuilding teacher professionalism in the United States, in: A. Hargreaves \& R. Evans (Eds) Beyond educational reform: bringing teachers back in (Buckingham, Open University Press), 77-93.

McLaughlin, M. W. \& Oberman, I. (Eds) (1996) Teacher learning: new policies, new practices (New York, Teachers College Record).

Merriam, S. B. (1998) Qualitative research and case study applications in education (San Francisco, Jossey-Bass).

Miles, M. B. \& Huberman, A. M. (1994) Qualitative data analysis: a sourcebook of new methods (California, Sage).

Ministry of Education (1998) National education policy 1998-2010 (Islamabad, Government of Pakistan).

Ministry of Education (2001) Education sector reforms: action plan 2001-2004 (Islamabad, Government of Pakistan).

Retallick, J. (1999) Teachers' workplace learning: towards legitimating and accreditation, Teachers and Teaching: theory and practice, 5(1), 33-50.

Retallick, J. \& Farah, I. (Eds) (2005) Transforming schools in Pakistan: towards the learning community (Karachi, Oxford University Press).

Rizvi, M. (2003) The relationships between school reforms and teacher professionalism in Government primary schools in Karachi, Pakistan. Unpublished doctoral dissertation, Queensland University of Technology, Australia.

Rizvi, M. \& Elliott, B. (2005) Teachers' perceptions of their professionalism in Government primary schools in Karachi, Pakistan, Asia-Pacific fournal of Teacher Education, 33(1), 35-52.

Simons, H. (1996) The paradox of case study, Cambridge fournal of Education, 26, 225-240.

Sindh Education Foundation (1998) Adopt a school program (Karachi, Sindh Education Foundation).

SPDC (2000) Social development in Pakistan: annual review 2000 (Karachi, Oxford University).

SPDC (2003) Social development in Pakistan: annual review 2002-03 (Karachi, Social Policy and Development Centre).

Tashakkori, A. \& Teddlie, C. (1998) Mixed methodology: combining qualitative and quantitative approaches (Thousand Oaks, Sage).

Teachers' Resource Centre (1999) The 13th annual report (Karachi, Teachers' Resource Centre).

The Book Group (1996) 27th quarterly progress report (Karachi, Book Group).

Yin, R. K. (2003) Case study research: design and methods (Thousand Oaks, Sage). 